\title{
PACKARD INSTRUMENT COMPANY RADIOCARBON DATES I
}

\author{
SANDRA J. KOWALSKI
}

Packard Instrument Company, Incorporated, Downers Grove, Illinois

The Low Level Counting Laboratory of Packard Instrument Company was organized and began operations in the fall of 1963 with the development and construction of the Packard Tri-carb ${ }^{\circledR}$ Benzene Synthesizer. This instrument is designed to consolidate into a small area $(6 \mathrm{ft} \times 8 \mathrm{ft})$ the equipment necessary to quickly and efficiently convert carbon-containing material or tritium water samples into benzene-an ideal solvent for liquid scintillation counting.

Analysis of samples by liquid scintillation with benzene as the counting solvent was chosen by the laboratory over other methods for several reasons:

1. Since benzene is a liquid and much more dense than a gas, more moles of carbon can be contained in a $20 \mathrm{ml}$ henzene-filled vial for liquid scintillation counting than can safely be compressed into a 1 or $2 \mathrm{~L}$ gas proportional counter. Thus, a higher net counting rate is obtained and the counting time is reduced.

2. Because of the excellent light transfer properties of benzene, it is known as one of the best counting solvents available (Noakes, Stipp. et al., 1964).

3. All six carbon atoms in the henzene molecule come from the sample to be dated.

4. Radioactive contamination and isotopic fractionation in the preparation of the benzene have never been noted in any benzene laboratory. Experimental work has shown that results are reproducible on a given sample even when the overall yield was varied over a wide range (Noakes, Kimm et al., 1964).

5. The troublesome radon impurity is completely eliminated during the chemical preparation of the sample to benzene. Final results, therefore. can be obtained much more rapidly than if another technique were to be used since there is no need to wait several weeks for the radon to decay before the sample can be counted.

6. Since each sample is contained in its own individual vial, there is no possibility of contamination from another sample, and it can be stored easily for future recounting if desired.

All samples are first cleaned physically by removing all small particles of foreign matter (i.e., rootlets, etc.) which might cause contamination. The samples are then boiled for 1 hour in dilute $(1 \%) \mathrm{HCl}$ to remove (arbonate contamination, and then rinsed with distilled $\mathrm{H}_{2}(\mathrm{O})$. Any contamination from humic acids is removed by boiling for several hours with dilute $11 \%$ ) $\mathrm{NaOH}$. This is followed by hoiling again with dilute $\mathrm{HCl}$ and sereral thorough rinsings with distilled $\mathrm{H}_{2}(\mathrm{O}$. After drying. the samples are ready for chemical conversion to benzene.

Radiocarbon dating. with benzene as the counting solvent. has been 
described by various researchers in recent years (Tamers et al., 1961; Stipp et al., 1962; Noakes et al., 1963; Léger and Tamers, 1963; Tamers et al., 1964). In the Packard laboratory a variation of the benzene method described in the literature is used. If the sample is organic, it is burned in an oxygen atmosphere to $\mathrm{CO}_{2}$. If it is inorganic, it is acidified to $\mathrm{CO}_{2}$. To convert to acetylene, the $\mathrm{CO}_{2}$ is admitted into an evacuated chamber containing molten lithium which has been heated to 600 to $650^{\circ} \mathrm{C}$, thus forming lithium carbide (H. Barker, personal commun.). When this reaction is complete, the chamber is cooled to room temperature and the carbide is hydrolyzed to form acetylene. The acetylene is passed over a purification column to remove any nitrogen products which could cause quenching in the counter (Tamers et al., 1964). The acetylene is then polymerized to benezene via catalysis. The benzene is pure and needs no further distillation before counting. It is poured directly into a pre-weighed counting vial and the carbon content is determined quantitatively. The sample benzene is diluted to $5 \mathrm{ml}$ with commercial spectro grade benzene and primary (PPO- $-0.4 \%$ by total scintillator solution volume) and secondary $\left(\left(\mathrm{CH}_{3}\right)_{2}\right.$ POPOP- $0.01 \%$ by total scintillator solution volume) scintillators are added.

The samples are counted in a Packard Tri-Carb ${ }^{\circledR}$ Liquid Scintillation Spectrometer Model 3214. This is an automatic unit which has two counting channels and a lister. A background vial and a $\mathrm{C}^{14}$ standard are always counted along with the sample vial which has a predetermined background count, and the preset time is set for $100 \mathrm{~min}$. This allows for as close to simultaneous background and sample counting as is possible and enables a check on any long term drift due either to instrument instability or environmental changes. The freezer temperature is set for $+6^{\circ} \mathrm{C}$, which is just slightly above the freezing temperature of benzene, to reduce thermal noise in the photomultiplier tubes and to prevent loss of the sample through evaporation. The discriminators are set to form adjacent channels and the channel ratios are checked routinely with calculations in order to verify the absence of quenching in each sample and also as an additional check on long term drift in the instrument.

The figure of merit $\left(\mathrm{E}^{2} / \mathrm{B}\right)$ of the Tri-Carb ${ }^{(\mathrm{R})}$ liquid scintillation spectrometer in our laboratory with a 5:1 discriminator setting and $5 \mathrm{ml}$ benzene as the total volume of scintillator solution is over 315 .

The contemporary reference used is $95 \%$ of the total activity of NBS oxalic-acid standard and gives a count rate of $8.5 \pm 0.1 \mathrm{cpm} / \mathrm{gm}$ carbon. Dates have been calculated using the Libby half-life value for $\mathrm{C}^{14}$ of $5570 \pm$ $30 \mathrm{yr}$ with 1950 as the standard year of reference.

\section{ACKNOWLEDGMENTS}

Samples were contributed and dates evaluated by Robert C. Becker of the Arctic Aeromedical Laboratory, U. S. Air Force, Ft. Wainwright, Alaska, John McNally, National Museum of Victoria, Melbourne, Australia, and F. J. Pearson, Radiocarhon Dating Laboratory, University of Texas.

Mr. J. J. Stipp was head of the laboratory at the time the samples reported here were analyzed. Dr. Ariel Schrodt contributed technical comments to the manuscript. 


\section{PIC-1. Appleton, Wisconsin}

Wood, spruce (Picea) from Appleton, Wisconsin, in SE1/4, Sec. 28, T21N, R17E (44. $29^{\prime} \mathrm{N}$ Lat, $88^{\circ} 25^{\prime} \mathrm{W}$ Long). Sample was imbedded in diagonal position in clayey red Valders till, $14 \mathrm{ft}$ below plain of glacial Lake Oshkosh; associated deposits included preglacial silt, sand, and gravel. Should be same age as Two Creeks Forest Bed. Wood from same find was previously dated as C-800, 10,856 \pm 410 (Chicago IV), an average of 11,471 \pm 500 and $10,241 \pm 650$; Lamont has an Appleton date, L-698D, 11,830 \pm 100 and an average of 11,840 for this and five other dates from Two Creeks Forest Bed (Broecker and Farrand, 1963); and Tamers obtained a date, Tx-44, of 10,700 \pm 210 (Texas II). Coll. before 1954 by William Read, Lawrence College, Appleton; subm. by M. A. Tamers, Radiocarbon Dating Lab., Univ. of Texas, Austin. Comment: sample was dated twice by this laboratory in independent analyses and both dates were in close agreement $(12,000 \pm 300$ and 12,260 $\pm 130)$; also in agreement with Chicago IV date $(10,856 \pm 410)$ and Lamont's date $(11,830 \pm 100)$.

\section{GEOLOGIC SAMPLES}

\section{Ready Bullion Creek series}

Samples from Ready Bullion Creek exposure of Pleistocene Muck $13 \mathrm{mi}$ W of Fairbanks, 1/2 mi NW of Ester, Alaska, in Ready Bullion Creek Valley $\left(64^{\circ} 51^{\prime} \mathrm{N}\right.$ Lat, $148^{\circ} 02^{\prime} \mathrm{W}$ Long $)$. The permafrost at this location is being continuously thawed and washed down the creek, exposing the bedrock below. There is a definite line of demarcation (a color change) between the bottom of the Wisconsin silt and the top of the Illinoian layer. The Wisconsin layer is approx. $34 \mathrm{ft}$ thick at this exposure.

\section{PIC-2. Ready Bullion Creek 1}

$$
\begin{gathered}
11,000 \pm 350 \\
9050 \text { в.с. }
\end{gathered}
$$

Wood from $20 \mathrm{ft}$ above base of Wisconsin age frozen silt at base of horizontally continuous peaty bed in the section. Comment: also dated by Univ. of Texas, Tx-160, as $9240 \pm 400$ (F. J. Pearson, Jr., oral commun.). Despite discrepancy between the two dates obtained by the laboratories, sample proved to be considerably more recent than original estimate of $30,000 \mathrm{yr}$.

\section{PIC-3. Ready Bullion Creek 2 \\ $8900 \pm 200$ 6950 в.c.}

Rich organic peaty material from $25 \mathrm{ft}$ above base of Wisconsin age frozen silt. Comment: purpose of measurement was to test validity of dates from silty peat material. Sample was found to be in same age range as PIC-6, as expected. It was also dated at Univ. of Texas as Tx-159, $8970 \pm 150$ (Texas III). This date is in close agreement with the one determined at the Packard lab. Sample is more recent than the original estimate of $20,000 \mathrm{yr}$.

\section{PIC-4. Ready Bullion Creek 3 \\ $10,340 \pm 475$ 8390 в.с.}

Silt with sparse organic material from $25 \mathrm{ft}$ above base of Wisconsin age 
frozen silt (same stratigraphic position as PIC-3). Comment: date agrees more closely with PIC-6, which was used as a control of the section, than did PIC-3 date.

\section{PIC-5. Ready Bullion Creek 4}

$8080 \pm 165$

Wood from base of recent deposits at top of Wisconsin age frozen silt which is $34.2 \mathrm{ft}$ above base. Comment: also dated at Univ. of Texas as Tx-157, $7740 \pm 170$ (Texas III). Date agrees with Packard date and suggests sample to be older than original estimate of $4000 \mathrm{yr}$.

\section{PIC-6. Ready Bullion Creek 5}

$10,450 \pm 150$

Tree root from $25 \mathrm{ft}$ above base of Wisconsin age frozen silt. Comment: sample was used as control of the section for the experimental work involved in testing the ability of obtaining valid dates from silty peat (PIC-3) and peaty silt (PIC-4) materials. Also dated at Univ. of Texas as Tx-158, 9410 \pm 130 (Texas III).

\section{PIC-7. Tidal River}

Marine molluscs (Homalina deltoidalis and Katelysia peroni) from emerged shell bed covered by peat of swampy flat in research area of Dept. of Botany, Univ. of Melbourne, near Tidal River, Wilson's Promontory, Gippsland, Victoria ( $39^{\circ} 02^{\prime} \mathrm{S}$ Lat, $146^{\circ} 29^{\prime} \mathrm{E}$ Long). Shell bed from which sample was taken is in sand, $4 \mathrm{ft}$ beneath a layer of sandy peat and a stand of Melaleuca ericofolia. Coll. 1963 by J. S. Turner, R. L. Specht, and A. M. Gill; subm. by John McNally, Director, and E. D. Gill, Curator of Fossils, Natl. Mus. of Victoria, Melbourne C1, Australia. Comment: sample dates (1) a described fauna, (2) maximum age of plant growth in the area, and (3) a higher stand of sea, which was followed by peat formation upon its retreat. Date agrees with estimated age of 4000 to $6000 \mathrm{yr}$.

\section{PIC-8. Hedley}

$4750 \pm 200$

\section{0 в.C.}

Marine molluses (Anadara Trapezia) from shell bed exposed in a long drain running $\mathrm{S}$ from Telegraph Road, Hedley, Gippsland. Victoria, Parish of Welshpool, sec. 34 of B (38 $49^{\prime} \mathrm{S}$ Lat, $146^{\circ} 39^{\prime} \mathrm{E}$ Long). Taken from $2.5 \mathrm{ft}$ to $3 \mathrm{ft}$ below surface. Coll. 1963 by E. D. Gill and H. E. Wilkinson; subm. by John McNally, Natl. Mus. of Victoria. Comment: sample dates the transgression of the sea. Date agrees with estimated age of 4000 to $6000 \mathrm{yr}$.

\section{PIC-9. Lake Pertobe}

$5850 \pm 320$

3900 в.с.

Shells of marine mollusc Homalina Deltoidalis from excavation 26, Lake. Pertobe, Cannon Hill, Warrnambool, Western Victoria $\left(38^{\circ} 23^{\prime} \mathrm{S}\right.$ Lat, $142^{\circ}$ $28^{\prime}$ E Long); from depth of $22 \mathrm{ft}$. Coll. 1950 by E. D. Gill; subm. by John McNally. Comment: sample dates post-glacial marine shells in an area not now reached by the sea and situated at the foot of a fossil cliff, Cannon Hill. It is overlain by peat and by the tuff of the volcano Tower Hill, thus providing maximum date for the volcanism. This is believed to be the latest activity in 
the basalt plain (about $9000 \mathrm{mi}^{2}$ ) of Western Victoria. Estimated age of 4000 to $6000 \mathrm{yr}$ agrees with date obtained in this laboratory.

PIC-10. Merri Canal

Shells of Homalina Deltoidalis from W bank of Merri Canal, one chain downstream from Warrnambool Woollen Mill and near the High Water Mark, Warrnambool, Western Victoria (38 $23^{\prime} \mathrm{S}$ Lat, $142^{\circ} 28^{\prime} \mathrm{E}$ Long) ; from emerged shell bed above high-tide level. Coll. 1963 by E. D. Gill; subm. by John MeNally. Comment: date confirms earlier estimate of 4000 to $6000 \mathrm{yr}$.

Date lists:

REFLRENCLS

$\begin{array}{ll}\text { Chicago IV } & \text { Libby, 1954 } \\ \text { Texas I } & \text { Stippet al., 1962 } \\ \text { Texas II } & \text { Tamers et al., } 1964 \\ \text { Texas III } & \text { Pearson et al., } 1965 \\ \text { Texas A \& M I } & \text { Noakes et al., 1964 }\end{array}$

Broecker, W. S., and Farrand, W. R., 1963, Radiocarbon age of the Two Creeks Forest Bed, Wisconsin: Geol. Soc. Am. Bull., v. 74, p. 795-802.

Léger, C., and Tamers, M. A., 1954, Chicago radiocarbon dates IV: Science, v. 119, p. $135-140$.

1963, The counting of naturally occurring radiocarbon in the form of benzene in a liquid scintillation counter: Int. Jour. Applied Radiation and Isotopes, v. 14, p. $65-70$.

Noakes, J. E., Isbell, A. F., Stipp, J. J., and Hood, D. W., 1963, Benzene synthesis by low temperature catalysis for radiocarbon dating: Geochim. et Cosmochim, Acta, v. 27, p. 797-804.

Noakes, John E., Stipp, J. J., and Hood, Donald W., 1964, Texas A \& M University radiocarbon dates I; Radiocarbon, v. 6, p. 189-193.

Noakes, J. E., Kimm, Stephen M., Thomas, Gerald A., and Akers, L. K., 1964, ORINS publication, no. 46, Oak Ridge, Tennessee.

Pearson F. J. Jr., Davis, E. Mott, Tamers, M. A., and Johnstone, Robert W., 1965, University of Texas radiocarbon dates III: Radiocarbon, v. 7, p. 296-314.

Stipp, J. J., Davis, E. Mott, Noakes, John E., and Hoover, Tom E., 1962, University of Texas radiocarbon dates I: Radiocarbon, v. 4, p. 43-50.

Tamers, M. A., Pearson, F. J., Jr., and Davis, E. Mott, 1964, University of Texas radiocarbon dates II: Radiocarbon, v. 6, p. 138-159.

Tamers, M. A., Stipp, J. J., and Collier, J., 1961, High sensitivity detection of naturally occurring radiocarbon: Chemistry of the counting sample: Geochim. et Cosmochim. Acta, v. 24, p. $266-276$ 